\title{
Phosphorus equivalency value of microbial phytase in weanling pigs fed a maize-soyabean meal based diet
}

\author{
J. S. Radcliffe and E. T. Kornegay ${ }^{1}$ \\ Department of Animal and Poultry Sciences, \\ Virginia Polytechnic Institute and State University \\ Blacksburg, VA 24061-0306, USA
}

(Received 27 October 1997; accepted 25 March 1998)

\begin{abstract}
Ninety-six crossbred pigs with an average initial weight of $10.3 \mathrm{~kg}$ were used in a 4-wk experiment to investigate the $P$ equivalency value of microbial phytase in weanling pigs using performance, rib mineralization and faecal digestibility measurements. A $19 \% \mathrm{CP}$, maize-soyabean meal basal diet low in $\mathrm{P}(0.35 \%)$ and $\mathrm{Ca}(0.50 \%)$ was fed. Diets $1,2,3$, and 4 contained $0,167,333$, and 500 units (U) of added Natuphos ${ }^{\circledR}$ phytase per $\mathrm{kg}$ of diet. respectively. Diets 5,6 , and 7 contained no added phytase, and $0.40,0.45$, and $0.50 \% \mathrm{P}$, respectively. Body weight and pen feed consumption were measured weekly. During wk 4, pen faecal samples were collected twice daily for $5 \mathrm{~d}$ for determination of P, Ca and DM digestibilities. At the end of wk 4, the barrow from each pen $(n=48)$ was killed for collection of tenth ribs for determination of rib shear force, and ash content. Adding phytase to low $\mathrm{P}$ diets linearly increased ( $\mathrm{P}<0.02$ to 0.001 ) ADG, rib shear force, rib ash weight and ash percent. Added $P$ linearly increased $(P<0.02$ to 0.001$)$ ADG, rib shear force, rib ash weight, and ash percent, $\mathrm{Ca}$ and $\mathrm{P}$ digestibility and digestible $\mathrm{Ca}$ and $\mathrm{P}$. Based on phytase and $\mathrm{P}$ linear or nonlinear response equations for ADG, $\mathrm{P}$ digestibility, rib ash weight and rib shear force, $500 \mathrm{U} / \mathrm{kg}$ of microbial phytase was equivalent to $1.03,0.78,0.89$, and $0.69 \mathrm{~g}$ of inorganic $\mathrm{P}$, respectively. The average equivalency of $500 \mathrm{U} / \mathrm{kg}$ of phytase was $0.84 \mathrm{~g}$ of $\mathrm{P}$ per $\mathrm{kg}$ of diet.
\end{abstract}

KEY WORDS: pigs, phytase, phosphorus, digestibility

\footnotetext{
${ }^{1}$ Corresponding autor: Dr. E.T. Kornegay, 3060 Litton-Reaves Hall, Virginia Tech, Blacksburg, VA 24061-0306, USA
} 


\section{INTRODUCTION}

Sixty to seventy percent of the $\mathrm{P}$ in plant ingredients, commonly used in pig diets, is bound as phytate P (Cromwell, 1992; Ravindran et al., 1994) which is unavailable to the pig (NRC, 1988). Several studies have demonstrated that the addition of microbial phytase improves $\mathrm{P}$ digestibility and therefore decreases $\mathrm{P}$ excretion by 25 to $50 \%$ when the level of supplemental P is lowered (Simons et al., 1990; Jongbloed et al., 1992; Kornegay, 1995).

For commercial pigs producers to take the greatest advantage of these beneficial effects of microbial phytase, $P$ equivalency values must be developed over a range of phytase and $P$ levels. Several studies have attempted to do this (Jongbloed et al., 1996a; Kornegay and Qian, 1996; Yi et al., 1996; Harper et al., 1997). However, in many of these studies diets containing wide Ca:P ratios (Jongbloed et al., 1996a; Kornegay and Qian, 1996; Yi et al., 1996) were fed, which have since been shown to decrease the efficacy of microbial phytase (Qian et al., 1996). In addition, several of the studies fed only two levels of P (Jongbloed et al., 1996a; Kornegay and Qian, 1996; Yi et al., 1996) which assumes that the P response is linear. Therefore, the variability seen in $\mathrm{P}$ equivalency values is large ranging from $0.52 \mathrm{~g}$ to $1.66 \mathrm{~g}$ per $500 \mathrm{U} / \mathrm{kg}$ phytase.

This study was designed to better delineate the $P$ equivalency value of phytase by feeding multiple levels of phytase and $\mathrm{P}$, while maintaining a narrow $\mathrm{Ca}: \mathrm{P}$ ratio, and by focusing on the linear and nonlinear response surfaces of both phytase and $P$.

\section{MATERIAL AND METHODS}

Ninety-six crossbred weanling pigs (equal barrows and gilts) were used in a 4-wk experiment to investigate the $P$ equivalency value of microbial phytase.

\section{Dietary treatments}

A $19 \%$ CP maize-soyabean meal diet fortified with vitamins and minerals to meet or exceed NRC (1988) requirements (except Ca and P) was fed in the 4-wk trial. Calcium was fed at a level of $0.50 \%$ of the diet for all treatments in order to maintain a more desirable $\mathrm{Ca}$ to $\mathrm{P}$ ratio (Table 1). Diets $1,2,3$, and 4 contained 3.5 $\mathrm{g}$ of total $\mathrm{P} / \mathrm{kg}$ of diet (no added P) and $0,167,333$, and $500 \mathrm{U}$ of added Natuphos ${ }^{\circledR}$ phytase per $\mathrm{kg}$ of diet, respectively. Diets 5,6 , and 7 contained no added phytase, and 4.0, 4.5, and 5.0 g of total $\mathrm{P} / \mathrm{kg}$ (supplemental $\mathrm{P}$ supplied by Biofos, Mallinckrodt Feed Ingredients, Mundelein, IL) of diet, respectively (Table 2). The ratio of $\mathrm{Ca}$ to $\mathrm{P}$ varied from 1.4:1 to $1: 1$ in the diets because the level of $\mathrm{P}$ was 
TABLE 1

Composition of basal diet

\begin{tabular}{lc}
\hline Ingredients & $\%$ \\
\hline Maize & 74.00 \\
Soyabean meal, $48.5 \%^{V_{\text {Vitamin premix }}^{\mathrm{a}}}$ & 23.20 \\
Trace mineral premix $^{\mathrm{b}}$ & 0.25 \\
Selenium premix $^{\mathrm{s}}$ & 0.10 \\
Limestone $^{\mathrm{d}}$ & 0.05 \\
Salt & 0.80 \\
L-lysine, $78 \%$ & 0.30 \\
Maize starch & \\
& 0.10 \\
Calculated composition & 1.20 \\
CP & \\
lysine & \\
total P & 17.5 \\
phytate P & 0.98 \\
available P & 0.356 \\
Ca & 0.228 \\
\hline
\end{tabular}

a supplied per kilogram of diet: 4400 IU of Vitamin A, 440 IU of Vitamin $D_{3}, 11$ IU of Vitamin E, $2.2 \mathrm{mg}$ of Vitamin K, $4.4 \mathrm{mg}$ of riboflavin, $22 \mathrm{mg}$ of calcium pantothenate, $22 \mathrm{mg}$ of niacin, 0.022 $\mathrm{mg}$ of vitamin $\mathrm{B}_{12}, 440 \mathrm{mg}$ of choline chloride, $0.44 \mathrm{mg}$ of biotin, $3.9 \mathrm{mg}$ of folic acid, $10 \mathrm{mg}$ of thiamin $\cdot \mathrm{HCl}, 3.9 \mathrm{mg}$ of pyridoxine $\cdot \mathrm{HCl}, 82.5 \mathrm{mg}$ of ethoxyquin and $3.6 \mathrm{mg}$ of virginiamycin

b supplied per kilogram of diel: $44 \mathrm{mg}$ of manganese, $47.5 \mathrm{mg}$ of zinc, $50 \mathrm{mg}$ of iron, $6.25 \mathrm{mg}$ of copper, and $2 \mathrm{mg}$ of iodine.

c supplied $0.3 \mathrm{mg}$ selenium per kilogram of diet.

d limestone (Limestone Dust Corp., Bluefield, VA).

e maize starch was replaced by phytase (Natuphos ${ }^{k}$ ) or MCP (Biophos: Malinckrodt Feed Ingredients, Mundelein, IL) in appropriate diets

changed while Ca remained constant. This should not have impacted our results because these ratios are within the suggested range of $1.5: 1$ to $1: 1$ (NRC, 1988). Twice as many pigs were fed diet $1(n=24)$ to insure a reliable baseline for phytase and $\mathrm{P}$ response curves. A chromic oxide-starch premix ( 1 part $\mathrm{Cr}_{2} \mathrm{O}_{3}: 3$ parts starch (wt:wt)) was added to all diets during wk 3 and 4 at a level of $0.2 \%\left(0.05 \% \mathrm{Cr}_{2} \mathrm{O}_{3}\right)$ as an indigestible indicator.

\section{Animal and feeding management}

The pigs were weaned at an average weight of $7.3 \mathrm{~kg}$ and given a $10-\mathrm{d}$ adjustment before treatments were started. During the adjustment pigs were fed a diet containing 22\% CP (Merrick's Soweena Day 14, Merrick's, Inc., Middleton, WI) 
TABLE 2

Dietary treatments ${ }^{a}$

\begin{tabular}{|c|c|c|c|c|c|}
\hline \multirow[b]{2}{*}{ Treatments } & \multirow{2}{*}{$\begin{array}{c}\text { Phytase, } \\
\text { U/kg }\end{array}$} & \multicolumn{2}{|c|}{ Calculated, $\%$} & \multicolumn{2}{|c|}{ Analyzed, \% } \\
\hline & & $\mathrm{Ca}$ & $\mathrm{P}$ & $\mathrm{Ca}$ & $\mathrm{P}$ \\
\hline 1 & 0 & 0.50 & 0.35 & 0.532 & 0.328 \\
\hline 2 & 167 & 0.50 & 0.35 & 0.532 & 0.328 \\
\hline 3 & 333 & 0.50 & 0.35 & 0.532 & 0.328 \\
\hline 4 & 500 & 0.50 & 0.35 & 0.532 & 0.328 \\
\hline 5 & 0 & 0.50 & 0.40 & 0.532 & 0.385 \\
\hline 6 & 0 & 0.50 & 0.45 & 0.532 & 0.435 \\
\hline 7 & 0 & 0.50 & 0.50 & 0.532 & 0.457 \\
\hline
\end{tabular}

a supplemental phytase supplied by Natuphos ${ }^{\text {ik }}$ and supplemental P supplied by Biofos (Mallinckrodt Feed Ingredients, Mundelein, IL).

for $3 \mathrm{~d}$ followed by a $20 \% \mathrm{CP}$ starter diet containing $10 \%$ dried whey and $0.10 \%$ mecadox (5.5 mg of carbadox per kilogram of diet) for the remaining $7 \mathrm{~d}$. Following the adjustment period, pigs were randomly assigned to treatments (6 replicate pens of one barrow and one gilt each, except diet 1 which had 12 replicate pens) from outcome groups based on gender and body weight. Littermates were balanced across treatments. The average BW was $10.2 \mathrm{~kg}$ at the start of treatments.

The pigs were housed in two similar environmentally controlled rooms with 24 $(0.61 \mathrm{~m} \times 0.91 \mathrm{~m})$ pens in each room. Room temperature was initially set at $29^{\circ} \mathrm{C}$ and was lowered about $2^{\circ} \mathrm{C}$ per week after the second week. A continuous lighting regimen and recommended air ventilation rates (Murphy et al., 1990) were maintained. Pigs had ad libitum access to feed and water at all times. The care and treatment of the animals followed published guidelines (Consortium, 1988).

\section{Sampling and analysis}

Body weight and pen feed consumption were measured weekly. During wk 4, pen faecal samples were collected twice daily $(0700$ and 1700) for $5 \mathrm{~d}$ and frozen at $-20^{\circ} \mathrm{C}$ in sealed plastic bags until drying at $65^{\circ} \mathrm{C}$ in a forced air oven. The dried faecal samples and samples of diets were ground to pass through a $1 \mathrm{~mm}$ sieve.

Diet and faecal samples were analyzed for $\mathrm{Ca}, \mathrm{P}$, and $\mathrm{Cr}$ following nitric-perchloric acid $(5: 3, \mathrm{vol} / \mathrm{vol})$ wet digestion. Total $\mathrm{P}$ concentrations were assayed photometrically by the vanadomolybdate procedure (AOAC, 1990) and $\mathrm{Ca}$ and $\mathrm{Cr}$ were determined with an atomic absorption spectrophotometer (model 5100 PC, Perkin Elmer, Norwalk, CT) using the manufacturer's recommendations. Dry matter was also determined for diet and faecal samples according to standard AOAC (1990) procedures. $\mathrm{P}, \mathrm{Ca}$ and $\mathrm{DM}$ digestibilities were calculated using the indirect method. 
At the end of wk 4, the barrow from each pen ( 6 pigs/treatment, except diet 1 , which had 12 pigs) was killed for collection of tenth ribs. The tenth ribs were cleaned of all tissues and used for determination of shear force and shear energy as described by Combs et al. (1991). Bone ash was determined in a muffle furnace at $600^{\circ} \mathrm{C}$ for $12 \mathrm{~h}$.

\section{Statistical analysis and calculation of equivalency values}

Data were separated into two groups, with phytase and with $\mathrm{P}$, and each was analyzed using the GLM procedures of SAS (1990). The model included replicate, phytase or $\mathrm{P}$, and the two-way interactions with replicate. Linear and quadratic contrasts were determined for phytase and $P$ levels. Nonlinear and linear equations of the effects of varying $P$ (no added phytase) and varying phytase levels on various measurements were derived (calculated values of $P$ and phytase were used). The nonlinear regression model used was $\mathrm{Y}=\mathrm{a}\left(1-\mathrm{be}^{-\mathrm{kX}}\right)$ and the linear regression model used was $\mathrm{Y}=\mathrm{a}+\mathrm{bX}$, where $\mathrm{Y}=$ response measurements; $\mathrm{X}=$ total phosphorus or added phytase. Functions which were highly correlated $\left(R^{2}>0.80\right)$ were used to generate equivalency values by setting the equations for phytase and $\mathrm{P}$ equal and solving. For example, the equation for overall $\mathrm{ADG}$ was as follows:

$$
\begin{aligned}
& 435.8-68.9 \mathrm{e}^{-0.0050 \mathrm{x}_{1}}=370.5+55.0 \mathrm{X} 2 \\
& \mathrm{X}_{2}=\left(65.3-68.9 \mathrm{e}^{-0.0050 \mathrm{x}}\right) / 55.0
\end{aligned}
$$

where $X_{1}=$ phytase $(U / \mathrm{kg})$ and $X_{2}=$ added inorganic $P(g / k g)$. These equations were then used to calculate equivalency values of $500 \mathrm{U} / \mathrm{kg}$ of phytase for supplemental P. For example, if $500 \mathrm{U} / \mathrm{kg}$ of phytase is supplemented in the above equation for $X_{1}$, then by solving for $X_{2}$ it is determined that based on the nonlinear/ linear response equation for phytase and $\mathrm{P}, 500 \mathrm{U} / \mathrm{kg}$ of phytase is equivalent to $1.08 \mathrm{~g}$ of total P.

\section{RESULTS}

\section{Phytase effects}

Average daily gain $(\mathrm{P}<0.001)$ during wk $3-4$ and overall average daily feed intake $(\mathrm{P}<0.05)$ linearly increased as the level of phytase in the diet increased (Table 3). ADG during wk 1-2 quadratically increased $(\mathrm{P}<0.04)$ as the level of phytase in the diet was increased. The overall linear effect of phytase on ADG in wk $1-4$ was significant $(P<0.001)$ with a $73 \mathrm{~g}$ increase in $\mathrm{ADG}$ at the highest level of phytase supplementation compared with the basal diet. The addition of phytase tended to linearly decrease $(\mathrm{P}=0.09)$ the amount of $\mathrm{P}$ excreted per day (Table 3$)$. 
TABLE 3

Effects of microbial phytase and inorganic P additions on ADG, ADFI (wk 1-4), and P excretion of weanling pigs fed a $P$ deficient maize-soyabean meal diet ${ }^{a}$

\begin{tabular}{|c|c|c|c|c|c|c|c|}
\hline \multirow[b]{2}{*}{ Treatment ${ }^{b}$} & \multirow{2}{*}{$\begin{array}{l}\mathrm{P} \\
\%\end{array}$} & \multirow{2}{*}{$\begin{array}{c}\text { Phytase } \\
\text { U/kg }\end{array}$} & \multicolumn{3}{|c|}{ ADG, g/d, week } & \multirow{2}{*}{$\begin{array}{cc}\text { ADFI } & P \\
g / d & \end{array}$} & \multirow{2}{*}{$\begin{array}{l}\text { P excreted } \\
\mathrm{g} / \mathrm{d}\end{array}$} \\
\hline & & & $\mathrm{I}-2$ & $3-4$ & $1-4$ & & \\
\hline \multicolumn{8}{|c|}{ Phytase effect } \\
\hline 1 & 0.35 & 0 & 267 & 460 & 363 & 866 & 2.23 \\
\hline 2 & 0.35 & 167 & 322 & 496 & 409 & 906 & 2.14 \\
\hline 3 & 0.35 & 333 & 316 & 517 & 417 & 998 & 2.16 \\
\hline 4 & 0.35 & 500 & 306 & 566 & 436 & 948 & 2.01 \\
\hline $\mathrm{MSE}^{\mathrm{d}}$ & & & 37 & 44 & 28 & 0.087 & 0.22 \\
\hline C.V., $\%$ & & & 12.4 & 8.8 & 7.0 & 9.5 & 10.0 \\
\hline \multicolumn{8}{|c|}{ Probability values } \\
\hline Treatment & & & 0.03 & 0.002 & 0.001 & 0.047 & 0.34 \\
\hline Lin Trt. & & & 0.10 & 0.001 & 0.001 & 0.049 & 0.10 \\
\hline Quad Trt. & & & 0.04 & 0.71 & 0.26 & 0.16 & 0.62 \\
\hline \multicolumn{8}{|l|}{ P effect } \\
\hline 1 & 0.35 & 0 & 267 & 460 & 363 & 866 & 2.23 \\
\hline 5 & 0.40 & 0 & 283 & 512 & 398 & 879 & 2.30 \\
\hline 6 & 0.45 & 0 & 366 & 512 & 439 & 915 & 2.43 \\
\hline 7 & 0.50 & 0 & 284 & 605 & 445 & 886 & 2.54 \\
\hline $\mathrm{MSE}^{\mathrm{d}}$ & & & 25 & 45 & 31 & 0.093 & 0.21 \\
\hline C.V., \% & & & 8.4 & 8.9 & 7.7 & 10.5 & 9.0 \\
\hline \multicolumn{8}{|c|}{ Probability values } \\
\hline Treatment & & & 0.003 & 0.009 & 0.01 & 0.69 & 0.104 \\
\hline Lin Trt. & & & 0.02 & 0.002 & 0.003 & 0.45 & 0.023 \\
\hline Quad Trt. & & & 0.003 & 0.30 & 0.27 & 0.50 & 0.867 \\
\hline
\end{tabular}

a each treatment mean represents six pens or 12 pigs, except diet 1 that has 12 pens or 24 pigs

b all diets contained $5 \mathrm{~g} / \mathrm{kg} \mathrm{Ca}$

c $\mathrm{P}$ excreted $(\mathrm{g} / \mathrm{d})=(100-\mathrm{P}$ digestbility $) / 100^{*}$ Diet $\mathrm{P}(\mathrm{g} / \mathrm{kg})^{*} \mathrm{ADFI}(\mathrm{g} / \mathrm{d})$

d $\mathrm{SEM}=$ Mean Square Error $(\mathrm{MSE}) / \mathcal{N}$, where $n=6$ or 12

Rib shear force $(\mathrm{P}<0.01)$ and ash percent $(\mathrm{P}<001)$ linearly increased as phytase was added to the diet (Table 4). Ash weight was quadratically increased $(\mathrm{P}<0.03)$ as the level of phytase added to the diet was increased. Linear increases were also observed for $\mathrm{Ca}(\mathrm{P}<0.001)$ and $\mathrm{P}(\mathrm{P}<0.001)$ digestibility and digestible $\mathrm{Ca}(\mathrm{P}<0.001)$ and $\mathrm{P}(\mathrm{P}<0.001)$ as the level of supplemental phytase in the diet was increased (Table 5). No effect was seen on DM digestibility $(\mathrm{P}=0.15)$. 
TABLE 4

Effects of microbial phytase and inorganic P additions on tenth rib bone mineralization of weanling pigs fed a $\mathrm{P}$ deficient maize-soyabean meal diet ${ }^{\mathrm{a}}$

\begin{tabular}{|c|c|c|c|c|c|}
\hline Treatment ${ }^{\mathrm{b}}$ & $\begin{array}{l}\mathrm{P} \\
\%\end{array}$ & $\begin{array}{c}\text { Phytase } \\
\text { U/kg }\end{array}$ & $\begin{array}{c}\text { Ash } \\
\text { weight, } g\end{array}$ & $\begin{array}{c}\text { Bone } \\
\text { ash, \% }\end{array}$ & $\begin{array}{c}\text { Shear } \\
\text { force, } N\end{array}$ \\
\hline \multicolumn{6}{|l|}{ Phytase effect } \\
\hline 1 & 0.35 & 0 & 0.606 & 39.5 & 442 \\
\hline 2 & 0.35 & 167 & 0.745 & 41.2 & 488 \\
\hline 3 & 0.35 & 333 & 0.851 & 42.0 & 500 \\
\hline 4 & 0.35 & 500 & 0.878 & 45.4 & 580 \\
\hline $\mathrm{MSE}^{\mathrm{c}}$ & & & 0.061 & 2.36 & 85.9 \\
\hline $\mathrm{CV}, \%$ & & & 8.3 & 5.7 & 17.5 \\
\hline \multicolumn{6}{|c|}{ Probability values } \\
\hline Treatment & & & 0.001 & 0.003 & 0.06 \\
\hline Lin Trt. & & & 0.001 & 0.001 & 0.01 \\
\hline Quad Trt. & & & 0.03 & 0.37 & 0.62 \\
\hline \multicolumn{6}{|l|}{ P effect } \\
\hline \multicolumn{6}{|l|}{1} \\
\hline 5 & 0.40 & 0 & 0.843 & 43.4 & 523 \\
\hline 6 & 0.45 & 0 & 0.954 & 45.4 & 627 \\
\hline 7 & 0.50 & 0 & 1.132 & 47.3 & 702 \\
\hline $\mathrm{MSE}^{\mathrm{c}}$ & & & 0.055 & 2.65 & 98.5 \\
\hline $\mathrm{CV}, \%$ & & & 6.5 & 6.1 & 17.9 \\
\hline \multicolumn{6}{|c|}{ Probability Values } \\
\hline Treatment & & & 0.001 & 0.01 & 0.02 \\
\hline Lin Trt. & & & 0.001 & 0.01 & 0.003 \\
\hline Quad Trt. & & & 0.25 & 0.44 & 0.98 \\
\hline
\end{tabular}

" each treatment mean represents six pens or 12 pigs, except diet 1 that has 12 pens or 24 pigs

b all diets contained $5 \mathrm{~g} / \mathrm{kg} \mathrm{Ca}$

- $\mathrm{SEM}=\mathrm{MSE} / \sqrt{ }$, where $\mathrm{n}=6$ or 12

\section{Phosphorus effects}

Average daily gain quadratically increased in wk $1-2(\mathrm{P}<0.003)$ and linearly increased in wk 3-4 ( $\mathrm{P}<0.002)$ as the level of $\mathrm{P}$ added to the diet increased (Table 3). The overall linear effect of $\mathrm{P}$ on ADG in wk 1-4 was significant $(\mathrm{P}<0.003)$ with a $83 \mathrm{~g}$ increase in $\mathrm{ADG}$ at the highest level of $\mathrm{P}$ supplementation compared with the basal diet. The addition of $\mathrm{P}$ had no effect on mean daily feed intake $(\mathrm{P}=0.45)$, but 
TABLE 5

Effects of microbial phytase and inorganic P additions on $\mathrm{P}, \mathrm{Ca}$, and $\mathrm{DM}$ digestibility (\%), and digested $(\mathrm{g} / \mathrm{kg}) \mathrm{P}$ and $\mathrm{Ca}$ of weanling pigs fed a $\mathrm{P}$ deficient maize-soyabean meal diet ${ }^{\mathrm{a}}$

\begin{tabular}{|c|c|c|c|c|c|c|c|}
\hline Treatment ${ }^{b}$ & $\begin{array}{l}\mathbf{P} \\
\%\end{array}$ & $\begin{array}{c}\text { Phytase } \\
\mathrm{U} / \mathrm{kg}\end{array}$ & $\begin{array}{c}\text { Ca dig } \\
\%\end{array}$ & $\begin{array}{c}P \operatorname{dig}^{c} \\
\%\end{array}$ & $\begin{array}{c}\text { DM dig } \\
\%\end{array}$ & $\begin{array}{c}\mathrm{DCa}^{\mathrm{d}} \\
\%\end{array}$ & $\begin{array}{c}\mathrm{DP}^{d} \\
\%\end{array}$ \\
\hline \multicolumn{8}{|c|}{ Phytase Effect } \\
\hline 1 & 0.35 & 0 & 54.2 & 21.5 & 87.3 & 0.34 & 0.08 \\
\hline 2 & 0.35 & 167 & 62.7 & 28.3 & 87.2 & 0.38 & 0.11 \\
\hline 3 & 0.35 & 333 & 64.6 & 34.3 & 87.7 & 0.40 & 0.13 \\
\hline 4 & 0.35 & 500 & 67.3 & 35.4 & 86.4 & 0.41 & 0.13 \\
\hline MSE $^{e}$ & & & 6.4 & 4.9 & 0.94 & 0.039 & 0.019 \\
\hline $\mathrm{CV}, \%$ & & & 10.5 & 17.3 & 1.1 & 10.5 & 17.3 \\
\hline \multicolumn{8}{|c|}{ Probability Values } \\
\hline Treatment & & & 0.003 & 0.001 & 0.13 & 0.003 & 0.001 \\
\hline Lin Trt. & & & 0.001 & 0.001 & 0.15 & 0.001 & 0.001 \\
\hline Quad Trt. & & & 0.49 & 0.15 & 0.12 & 0.31 & 0.17 \\
\hline \multicolumn{8}{|l|}{$P$ effect } \\
\hline 1 & 0.35 & 0 & 54.2 & 21.5 & 87.3 & 0.34 & 0.08 \\
\hline 5 & 0.40 & 0 & 63.5 & 32.0 & 86.1 & 0.39 & 0.14 \\
\hline 6 & 0.45 & 0 & 68.3 & 39.1 & 86.7 & 0.42 & 0.20 \\
\hline 7 & 0.50 & 0 & 66.5 & 37.1 & 85.9 & 0.41 & 0.20 \\
\hline $\mathrm{MSE}^{\mathrm{e}}$ & & & 7.1 & 4.9 & 1.26 & 0.044 & 0.019 \\
\hline $\mathrm{CV}, \%$ & & & 11.5 & 16.2 & 1.5 & 11.6 & 13.1 \\
\hline \multicolumn{8}{|c|}{ Probability values } \\
\hline Treatment & & & 0.04 & 0.001 & 0.27 & 0.04 & 0.001 \\
\hline Lin Trt. & & & 0.02 & 0.001 & 0.19 & 0.02 & 0.001 \\
\hline Quad Trt. & & & 0.10 & 0.02 & 0.76 & 0.11 & 0.005 \\
\hline
\end{tabular}

a each treatment mean represents six pens or 12 pigs, except diet 1 that has 12 pens or 24 pigs

${ }^{b}$ all diets contained $5 \mathrm{~g} / \mathrm{kg} \mathrm{Ca}$.

c digestion coefficient for $\mathrm{Ca}$ or $\mathrm{P}$ as a percentage

digestible $\mathrm{Ca}$ or $\mathrm{P}$ as a percent of the diet

e $\mathrm{SEM}=\mathrm{MSE} / \sqrt{ }$, where $\mathrm{n}=6$ or 12

the amount of $\mathrm{P}$ excreted per day was linearly increased (Table $3 ; \mathrm{P}<0.03$ ). Rib shear force $(\mathrm{P}<0.003)$, ash weight $(\mathrm{P}<0.001)$, and ash percent $(\mathrm{P}<0.01)$ linearly increased as $\mathrm{P}$ was added to the diet (Table 4). The addition of $\mathrm{P}$ to the basal diet also linearly improved $\mathrm{Ca}(\mathrm{P}<0.02)$ digestibility and digestible $\mathrm{Ca}(\mathrm{P}<0.02$; Table 5). Phosphorus digestibility $(\mathrm{P}<0.02)$ and digestible $\mathrm{P}(\mathrm{P}<0.005)$ were quadratically improved with phytase addition. No effects were seen on DM digestibility $(\mathrm{P}=0.19)$. 


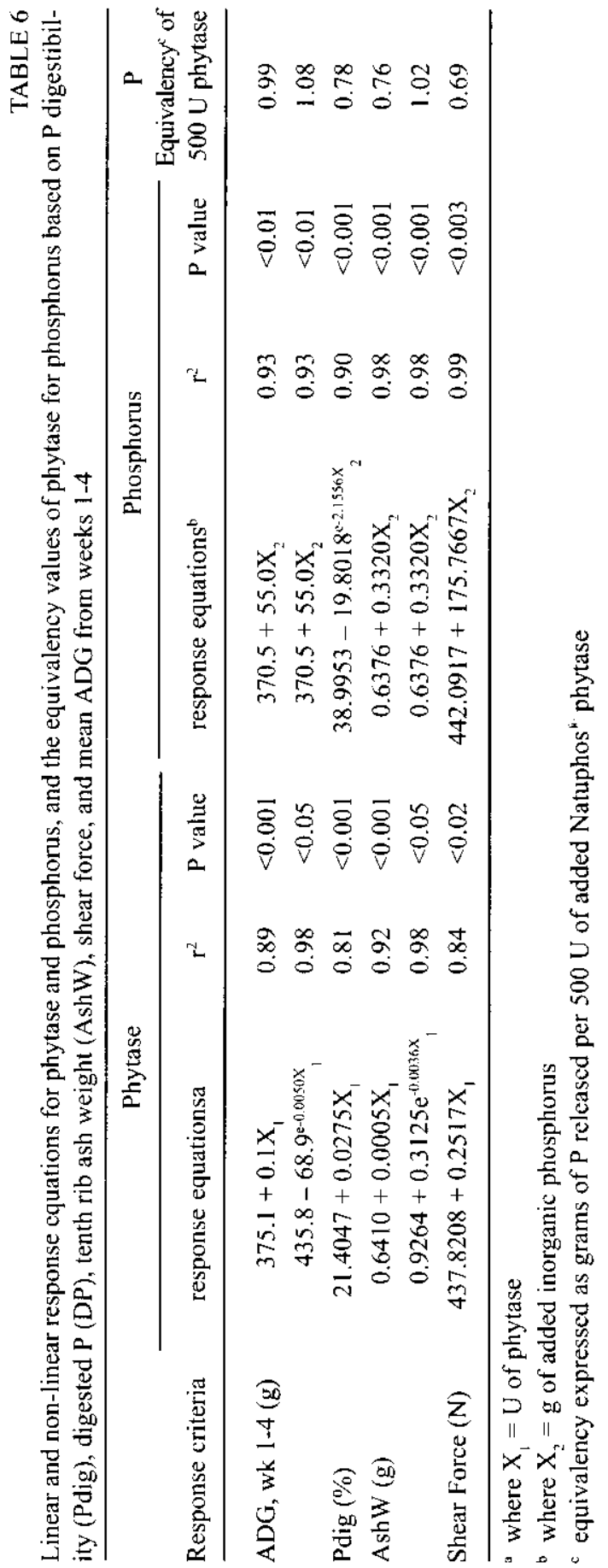


Equations and equivalency values

ADG during wk 1-4, rib shear force, ash weight, and P digestibility were all responsive to the effects of phytase and $\mathrm{P}$; therefore, the nonlinear or linear equation for each main effect with the highest $r^{2}$ value was chosen for calculation of $P$ equivalency values of phytase (Table 6). If both linear and nonlinear equations provided good fits $\left(r^{2}>0.80\right)$, then they were both used to calculate equivalency values and the average value is reported. The $P$ equivalency values of phytase were obtained by setting the equations for phytase and $P$ equal and solving. Equivalency values for $500 \mathrm{U}$ of phytase/ $\mathrm{kg}$ of diet based on ADG, P digestibility, rib ash weight and rib shear force were $1.03,0.78,0.89$, and $0.69 \mathrm{~g}$ of inorganic $\mathrm{P}$, respectively. The average equivalency of $500 \mathrm{U} / \mathrm{kg}$ of phytase was $0.84 \mathrm{~g}$ of P per $\mathrm{kg}$ of diet.

\section{DISCUSSION}

Phosphorus is an essential element required by pigs for optimal growth, reproduction and bone development. Much of the P in pig diets is unavailable to the pig because it is bound as phytate P. Approximately $66 \%$ of the P in maize and $61 \%$ of the $P$ in soyabean meal is complexed in phytate $P$ (Ravindran et al., 1994). Therefore, producers have to add large amounts of inorganic $P$ to pig diets in order to meet the needs of the pigs; this adds to the cost of the diet and results in increased $\mathrm{P}$ excretion which could lead to environmental pollution problems. According to the NRC (1988), a $10-20 \mathrm{~kg}$ pig requires an $18 \% \mathrm{CP}$ diet containing $0.32 \% \mathrm{aP}$. A maize-soyabean meal based diet formulated to contain $18 \% \mathrm{CP}$ contains $0.38 \% \mathrm{tP}$. Theoretically, if all of this $\mathrm{P}$ was available it would be enough to meet the pigs requirement for $\mathrm{P}$. However, since approximately $85 \%$ of the $\mathrm{P}$ in maize and $75 \%$ of the $\mathrm{P}$ in SBM (48.5\%) is unavailable to the pig (NRC, 1988), the diet contains only $0.068 \%$ aP and a highly available inorganic source of $\mathrm{P}$ must be supplemented to the diet.

Ruminants can utilize phytate $\mathrm{P}$ because microbes within the rumen produce the enzyme phytase which hydrolyzes the phytate molecule releasing the bound $\mathrm{P}$; however, pigs and poultry only have trace amounts of phytase in their digestive tract. The potential to release $\mathrm{P}$ bound by phytate through the addition of exogenous phytase to broiler diets was shown nearly 30 years ago (Nelson et al., 1968). However, it has not been until recently, through advancements in genetic engineering, that an affordable method of producing microbial phytase has been available. Many studies have documented the ability of microbial phytase to enhance $\mathrm{P}$ digestibility and thus decrease P excretion (Jongbloed, 1996b; reviewed by Kornegay, 1996). With commercially produced phytase now available to swine pro- 
ducers it is essential that accurate equivalency values of phytase for $\mathrm{P}$ be derived. This needs to be done for two reasons. First to minimize the cost of adding microbial phytase, and second to minimize the amount of $P$ excreted in pig manure.

As the level of $P$ was increased in the diets with no added phytase, the amount of $P$ excreted per day was increased. Phytase supplementation numerically decreased the amount of $P$ excreted per day, but this effect was not significant. However, since phytase increased ADG, the amount of $P$ excreted per unit of gain was decreased. Using the data presented in Table 3, the amount of $P$ excreted per unit of gain can be calculated. Pigs fed the basal diet (diet 1) gained on average $363 \mathrm{~g} / \mathrm{d}$ in wk $1-4$ and excreted on average $2.23 \mathrm{~g} / \mathrm{d}$. This represents $0.61 \mathrm{~g}$ of $\mathrm{P}$ excreted per $100 \mathrm{~g}$ of gain. Pigs fed diet 4 which was supplemented with $500 \mathrm{U} / \mathrm{kg}$ of phytase gained on average $436 \mathrm{~g} / \mathrm{d}$ in wk $3-4$ and excreted on average $2.01 \mathrm{~g} / \mathrm{d}$. This represents $0.46 \mathrm{~g}$ of $\mathrm{P}$ excreted per $100 \mathrm{~g}$ of gain. Therefore, $\mathrm{P}$ excretion was decreased approximately $24.6 \%$ per unit of gain when pigs were fed diets supplemented with $500 \mathrm{U} / \mathrm{kg}$ of phytase. The estimated equivalency value of $500 \mathrm{U} / \mathrm{kg}$ phytase for $P$ derived from this study was $0.83 \mathrm{~g}$. Which means, that pigs fed a diet which contained $3.5 \mathrm{~g}$ total $\mathrm{P}$ and $500 \mathrm{U} / \mathrm{kg}$ phytase should have similar performance to pigs fed a diet with approximately $4.3 \mathrm{~g}$ of total $\mathrm{P}$. If we use the data from Table 3 and use the same calculations as above, we estimate that pigs fed $4.0 \mathrm{~g} / \mathrm{kg}$ of $P$ and no added phytase excreted $0.58 \mathrm{~g}$ P per $100 \mathrm{~g} \mathrm{BW}$ gain in wk $1-4$ and pigs fed 4.5 $\mathrm{g} / \mathrm{kg}$ of $\mathrm{P}$ and no added phytase excreted $0.55 \mathrm{~g} \mathrm{P}$ per $100 \mathrm{~g} \mathrm{BW}$ gain in wk 1-4. Therefore, adding $500 \mathrm{U} / \mathrm{kg}$ of phytase in place of this $P$ represents between a $20.7 \%$ and a $16.4 \%$ decrease in $\mathrm{P}$ excretion per unit of $\mathrm{BW}$ gain. Similar results have been reported in the literature with many studies reporting a 25 to $50 \%$ reduction in P excretion (Jongbloed et al., 1992; Lei et al., 1993b, Kornegay and Qian, 1996; Yi et al., 1996).

The results of this study clearly demonstrate the beneficial effects of microbial phytase addition to a low $\mathrm{P}$ maize-soyabean meal based pig diet. Growth performance, rib mineralization and $P$ digestibility were all improved when phytase was added to the diet. This is in agreement with studies in the literature which have demonstrated increased daily gains and feed intakes (Beers and Jongbloed, 1992; Jongbloed et al., 1992; Kornegay and Qian, 1996, Yi et al., 1996), increased bone breaking strength or shear force (Kornegay and Qian, 1996; Yi et al., 1996) and increases in P digestibility or retention (Hoppe et al., 1992; Lei et al, 1993a,b; Mroz et al., 1994; Kornegay and Qian, 1996; Yi et al., 1996) when pigs are fed diets supplemented with phytase.

Several studies have attempted to determine the $P$ equivalency value of phytase in pigs (Jongbloed et al., 1996a; Kornegay and Qian, 1996; Yi et al., 1996; Harper et al., 1997). The range of equivalency values for $500 \mathrm{U} / \mathrm{kg}$ phytase is larger ranging from $0.64 \mathrm{~g}$ P to $2.47 \mathrm{~g}$ P. Factors which may influence these equivalency value estimates include: the basal level of $P$, the age of the animal, the response 
criteria used, and perhaps most importantly the ratio of Ca to P. Qian et al. (1996) reported a detrimental effect of a widening Ca:tP ratio in excess of $1.2: 1$ on phytase efficacy in pigs. In the pig studies of Jongbloed et al. (1996a), Kornegay and Qian (1996), and Yi et al. (1996) only two levels of $\mathrm{P}$ were fed, so the response of various criteria to $P$ was assumed to be linear. In addition the $\mathrm{Ca}: \mathrm{P}$ ratio in the studies of Kornegay and Qian (1996) and Yi et al. (1996) was 2:1. In the study by Jongbloed et al. (1996a) the Ca:tP ratio ranged from 1.94:1 to 2.5:1. Harper et al. (1997) in a study with growing-finishing pigs utilized three levels of $P$ and maintained a Ca:tP ratio of approximately $1.2: 1$ to $1.4: 1$ in all diets. They reported that $500 \mathrm{U}$ of microbial phytase releases $0.96 \mathrm{~g}$ of $\mathrm{P}$ per kilogram of diet.

In the experiment reported here, multiple levels of phytase and $P$ were used for deriving response equations for various criteria so that equivalency estimates could be made. In addition, the Ca:tP ratio was maintained in all phytase supplemented diets at $1.42: 1$ in an attempt to maintain an optimal $\mathrm{Ca}: \mathrm{P}$ ratio for phytase efficacy. Because of positive linear and/or quadratic effects of both phytase and P additions and the goodness of fit $\left(r^{2}>0.80\right)$ of the linear or nonlinear equations, ADG, rib shear force, ash weight, and $\mathrm{P}$ digestibility were used to develop equivalency values. The range in equivalency values was from $0.69 \mathrm{~g} \mathrm{P}$ to $1.03 \mathrm{~g}$ of $\mathrm{P}$ from monocalcium phosphate (MCP) being equivalent to $500 \mathrm{U}$ of phytase per $\mathrm{kg}$ of diet with the average being $0.84 \mathrm{~g} \mathrm{P}$ equal to $500 \mathrm{U}$ of phytase per $\mathrm{kg}$ of diet. The $\mathrm{P}$ in MCP is generally considered to be $95-100 \%$ available (Baker, 1991; Soares, 1995). Therefore, based on the results of our study $500 \mathrm{U} / \mathrm{kg}$ of phytase releases $0.84 \mathrm{~g}$ digestible $\mathrm{P}$. This value seems to be in agreement with the findings of Jongbloed et al. (1996a) who found in several studies that 500 to $2000 \mathrm{U}$ of microbial phytase released between 0.8 and $1.0 \mathrm{~g}$ of digestible P. Equivalency values based on growth data provided the highest equivalency estimates. Digestibility data and bone parameters were slightly more conservative estimators of $P$ equivalency values.

Results from this study also demonstrate the ability of phytase to increase the digestibility of $\mathrm{Ca}$. $\mathrm{Ca}$ digestibility was increased by $8.5,10.4$, and $13.1 \%$ units with the addition of 167,333 , and $500 \mathrm{U}$ of phytase per $\mathrm{kg}$ of diet. Nelson et al. (1968) found that as the level of phytic acid in the diet increased, so did the chicks requirement for $\mathrm{Ca}$. Several studies have reported improved $\mathrm{Ca}$ digestibility in pigs when microbial phytase was added to the diet (Mroz et al., 1993; Radcliffe et al., 1995; Kornegay and Qian, 1996; Yi et al., 1996a). With the release of Ca, in addition to $\mathrm{P}$ when phytase is added to pig diets, the optimal $\mathrm{Ca}: \mathrm{P}$ ratio needs to be reexamined. The NRC (1988) reports that the optimal Ca:P ratio in pig diets is between $1: 1$ and 1.5:1 for grain-soyabean meal based diets. However, when phytase was added to pig diets Qian et al. (1996) found that $P$ digestibility was decreased when the Ca:tP ratio was increased from 1.2:1 to $1.6: 1$. Ideally, the $\mathrm{Ca}: \mathrm{P}$ ratio should be based on available $\mathrm{Ca}$ and $\mathrm{P}$ instead on total $\mathrm{Ca}$ and $\mathrm{P}$. However, many more studies are needed to generate a reliable data base for available $\mathrm{Ca}$ and $\mathrm{P}$ 
values from various grain sources. In addition, accurate equivalency values of phytase for Ca will need to be developed.

\section{CONCLUSIONS}

The addition of microbial phytase to P-deficient diets fed to weanling pigs causes improvements in growth performance, bone mineralization, $\mathrm{P}$ and $\mathrm{Ca}$ digestibility, and decreases $\mathrm{P}$ excretion. Based on response equations developed in this study, $500 \mathrm{U} / \mathrm{kg}$ of phytase releases $0.84 \mathrm{~g}$ of $\mathrm{P}$. Therefore, pig diets can be supplemented with microbial phytase, the amount of inorganic $\mathrm{P}$ (and $\mathrm{Ca}$ ) added can be decreased, and the result will be equivalent performance and decreased $P$ excretion.

\section{ACKNOWLEDGMENTS}

The authors wish to thank D. E. Conner, Jr. and L. Flory for lab assistance and to C. J. Hixon for help with manuscript preparation. Special thanks is given to the BASF Corporation and the John Lee Pratt Animal Nutrition Program for financial support.

\section{REFERENCES}

AOAC, 1990. Official Methods of Analysis. $15^{\text {th }}$ Edition Association of Official Analytical Chemists, Arlington, VA

Baker D.H., 1991. Bioavailability of minerals and vitamins. In: E. R. Miller, D. E. Ullrey, A. J. Lewis (Editors). Swine Nutrition. Butterworth-Heinemann, Stoneham, MA, pp. 341

Beers S.B.M., Jongbloed A.W., 1992. Effect of supplementary Aspergillus niger phytase in diets for piglets on their performance and apparent digestibility of phosphorus. Anim. Prod. 55, 425

Combs N.R., Kornegay E.T., Lindemann M.D., Notter D.R., Wilson J.H., Mason J. W., 1991. Calcium and phosphorus requirement of swine from weaning to market: II. Development of response curves for bone criteria and comparison of bending and shear bone testing. J. Anim. Sci. 69 , 682-693

Consortium, 1988. Guide For the Care and Use of Agricultural Animals in Agricultural Research and Teaching. Consortium For Developing a Guide For the Care and Use of Agricultural Animals in Agricultural Research and Teaching, Champaign, IL.

Cromwell G.L., 1992. The biological availability of phosphorus from feedstuffs. Pig News Inf. 13. $75 \mathrm{~N}-78 \mathrm{~N}$

Harper A.F., Kornegay E.T., Schell T.C., 1997. Phytase supplementation of low phosphorus growing-finishing pig diets improves performance, phosphorus digestibility and bone mineralization, and reduces phosphorus excretion. J. Anim. Sci. 75, 3174-3186 
Hoppe P.P., Schoner F.J., Wiesche H., Schwartz G., 1992. Verglich von mikrobieller phytase und anorganischem phosphate bei ferkeln: effekte auf die leitungen, die mineralstoff-retention und den mineralstoffgehalt der phalanx I. Poster, 45, Tagng der GEH, Gottingen

Jongbloed A.W., Kemme P.A., Mroz Z., 1996a. Effectiveness of natuphos phytase in improving the bioavailabilities of phosphorus and other nutrients for growing-finishing pigs. In: M.B. Coelho, E.T. Kornegay (Editors). Phytase in Animal nutrition and waste management. BASF Corporation, Mount Olive, NJ, pp. 393

Jongbloed A.W., Kemme P.A., Mroz Z., 1996b. Phytase in swine rations: impact on nutrition and environment. BASF Technical Symposium, Des Moines, Iowa, p. 44

Jongbloed A.W., Mroz Z., Kemme P. A., 1992. The effect of supplementary Aspergillus niger phytase in diets for pigs on concentration and apparent digestibility of dry matter, total phosphorus, and phytic acid in different sections of the alimentary tract. J. Anim. Sci. 70, 1159-1168

Kornegay E.T., 1995. Important considerations for using microbial phytase in swine diets. BASF Technical Symposium, Champaign, IL, pp. 28-50

Kornegay E.T., 1996. Natuphos ${ }^{\mathrm{TM}}$ phytase in swine diets: digestibility, bone and carcass characteristics. BASF Technical Symp., Raleigh, NC, pp. 28-67

Kornegay E. T., Qian H., 1996. Replacement of inorganic phosphorus by microbial phytase for young pigs fed on a maize-soyabean meal diet. Brit. J. Nutr. 76, 563-578

Lei X.G., Ku, P.K., Miller E.R., Yokoyama M. T., 1993a. Supplementing maize-soyabean meal diets with microbial phytase linearly improves phytate phosphorus utilization by weanling pigs. $\mathrm{J}$. Anim. Sci. 71, 3359-3367

Lei X.G., Ku P.K., Miller E.R., Yokoyama M.T., Ullrey D.E., 1993b. Supplementing maize soyabean meal diets with microbial phytase maximum phytate phosphorus utilization by weanling pigs. J. Anim. Sci. 71, 3369-3375

Mroz Z., Jongbloed A.W., Kemme P.A., 1994. Apparent digestibility and retention of nutrients bound to phytate complexes as influenced by microbial phytase and feeding regimen in pigs. J. Anim. Sci. 72, 126-132

Mroz Z., Jongbloed A.W., Kemme P.A., Geerse K., 1993. Digestibility and urinary losses of calcium and phosphorus in pigs fed a diet with suboptimal levels of both elements and graded doses of microbial phytase (Natuphos ${ }^{\circledR}$ ), Enzymes in Animal Nutrition Procceedings of 1st Symposium-Kartause Ittingen (Switzerland), pp. 217-221

Murphy J.P., Jones D.D., Christianson L.L., 1990. Mechanical ventilation of swine buildings. In: Pork Industry Handbook \#60. Purdue Univ., West Lafayette, IN

Nelson T.S., McGillivray J.J., Shieh T.R., Wodzinski R.J., Ware J.H., 1968. Effect of phytate on the calcium requirement of chicks. Poultry Sci. 47, 1985-1989

NRC, 1988. Nutrient Requirements of Swine, 9th Edition. National Academy Press, Washington, DC

Qian H., Kornegay E.T., Conner D.E., 1996. Adverse effects of wide calcium:phosphorus ratios on supplemental phytase efficacy for weanling pigs fed two dietary phosphorus levels. J. Anim. Sci. 74, 1288-1297

Radcliffe J.S., D.E. Conner Jr., E.T. Kornegay, 1995. The effect of phytase on calcium release in weanling pigs fed maize-soyabean meal diets. J. Anim. Sci. 73, Suppl. 1, 173

Ravindran V., Ravindran G., Sivalogan S., 1994. Total and phytaet phosphorus contents of various foods and feedstuffs of plant origin. Food Chem. 50, 133-136

SAS, 1990. SAS/STAT User's Guide: Statistics (Release 6.04 Ed.). SAS Inst. Inc., Cary, NC

Soares, J. H., Jr., 1995. Calcium bioavailability. In: C. B. Ammerman, D. H. Baker, A. J. Lewis (Editors). Bioavailability of nutrients for animals. Academic Press, Inc., San Diego, CA. pp. 95 
Yi Z., Kornegay E.T., Lindemann M.D., Ravindran V., Wilson J.H., 1996. Effectiveness of Natuphos $(\mathbb{B}$ phytase in improving the bioavailabilities of phosphorus and other nutrients in soyabean meal-based semipurified diets for young pigs. J. Anim. Sci. 74, 1601-1611

\section{STRESZCZENIE}

\section{Równowartość dodatku fosforu lub mikrobiologicznej fitazy u odsadzonych prosiąt żywionych kukurydziano-sojową dawką}

Na dziewięćdziesięciu odsadzonych prosiętach mieszańcach, o początkowej masie ciała 10,3 kg, w 4-ro tygodniowym doświadczeniu oznaczano równowartość dodatku fitazy mikrobiologicznej lub fosfonu, przyjmując jako kryteria oceny : wyniki odchowu, stopień mineralizacji żeber oraz pozorną strawność składników pokarmowych dawki. Podstawowa dawka, kukurydziano-sojowa. zawierała $19 \%$ białka ogólnego oraz $3,5 \mathrm{~g} / \mathrm{kg} \mathrm{P}$ (niski poziom) i $5,0 \mathrm{~g} / \mathrm{kg} \mathrm{Ca}$. Do dawek 1, 2, 3 i 4 dodawano preparat fitazy Natuphos" ${ }^{\mathrm{N}}$ w ilości $0,167,333$ i 500 jednostek (U), odpowiednio na $1 \mathrm{~kg}$ diety. Do diet 5,6 i 7 zamiast fitazy dodawano 4,$0 ; 4,5$ i 5,0\% P/kg, odpowiednio. Co tydzień kontrolowano przyrosty i spożycie paszy. W 4-ym tygodniu, przez 5 dni, pobierano próby kału 2 razy dziennie w celu oznaczenia strawności $\mathrm{P}, \mathrm{Ca}$ i s.m. Na końcu 4-go tygodnia ubito wieprzki $(n=48)$ z każdej grupy i pobrano 10-te żebro dla oznaczenia sily lamania żebra i zawartości popiołu. Dodatek fitazy do niskofosforowej diety spowodował liniowe $(\mathrm{P}<0,02$ do 0,001$)$ zwiększenie przyrostów dziennych, siły łamania żebra, masy $\mathrm{i}$ procentu popiołu w żebrze. Dodatek $\mathrm{P}$ zwiększył liniowo $(P<0,02$ do 0,001$)$ przyrosty dzienne, siłę łamania żebra, masę i procent popiołu, strawność Ca i $\mathrm{P}$ oraz ilość strawnego Ca i $\mathrm{P}$.

Przyjmując za podstawę porównań przyrosty dzienne, siłę łamania żebra i masę popiołu, a także strawność P j zawartość strawnego P obliczono, że dodatek fitazy mikrobiologicznej w ilość $500 \mathrm{U} / \mathrm{kg}$ diety zastępuje odpowiednio 0,$99 ; 0,69 ; 0,71 ; 0,82$ i $0,96 \mathrm{~g}$ P nieorganicznego. Średnio równoważna wartość $500 \mathrm{U}$ titazy $/ \mathrm{kg}$ diety odpowiadała $0,84 \mathrm{~g} \mathrm{P} / \mathrm{kg}$ diety. 